\title{
ANALISIS KUALITAS PELAYANAN JASA TERHADAP KEPUASAN PELANGGAN PADA CV. AHASS KABUL MOTOR KECAMATAN LEMBEYAN KABUPATEN MAGETAN
}

\author{
Sudarmiani \\ Dosen Prodi Pendidikan Ekonomi \\ Yudha Allan Afri Fiyanto \\ Mahasiswa Prodi Pendidikan Ekonomi
}

\begin{abstract}
The study describes the quality of service, namely Tangible Responsiveness, Reliability (Reliability) and Assurance (Assurance) against Customer Satisfaction CV. AHASS Kabul Lembeyan Magetan Subdistrict motors. The method in this research is descriptive quantitative method while sampling technique in this research is quota sampling technique that customer in Kabul AHASS Lembeyan Magetan Subdistrict motorcycle that comes to CV. AHASS when distributing questionnaires were 30 respondents. Collecting data using questionnaires, documentation. Analysis of data using linear regression analysis. The results showed that the quality of service on the CV. AHASS Kabul Motor Magetan Subdistrict Lembeyan well. It can be seen from the results of the analysis with the amount of data as much as 30 customers results above the average value (62) as many as 17 customers or $57 \%$ below average, while as many as 13 or $43 \%$. Customers CV. AHASS Kabul Motor Lembeyan Magetan satisfied with the services that have been received. It can be seen from the results of the analysis with the amount of data as much as 30 customers angketnya value customers results above average above average (42.90) as many as 18 or $60 \%$ of customers while below average as many as 12 customers or $40 \%$.
\end{abstract}

Keywords: Service Quality, Customer Satisfaction

Abstrak: Penelitian memaparkan kualitas pelayanan jasa, yaitu Tangible Responsiveness, Reliability (Keandalan), dan Assurance (Kepastian) terhadap Kepuasan Pelanggan pada CV. AHASS Kabul motor Kecamatan Lembeyan Kabupaten Magetan. Metode dalam penelitian ini adalah metode Deskriptif kuantitatif sedangkan teknik pengambilan sampel dalam penelitian ini adalah teknik quota sampling yaitu pelanggan pada AHASS Kabul motor Kecamatan Lembeyan Kabupaten Magetan yang datang ke CV. AHASS pada saat penyebaran angket berjumlah 30 responden. Pengumpulan data menggunakan metode kuesioner, dokumentasi. Analisis data menggunakan analisis regresi linier. Hasil penelitian menunjukkan bahwa kualitas pelayanan jasa pada CV. AHASS Kabul Motor Kecamatan Lembeyan Kabupaten Magetan baik. Hal ini dapat diketahui dari hasil analisis dengan jumlah data sebanyak 30 pelanggan pelanggan yang hasil angketnya nilai di atas ratarata(62) sebanyak 17 pelanggan atau 57\% sedangkan di bawah rata-rata sebanyak 13 atau 43\%. Pelanggan CV. AHASS Kabul Motor Lembeyan Kabupaten Magetan puas dengan pelayanan jasa yang telah diterima. Hal ini dapat diketahui dari hasil analisis dengan jumlah data sebanyak 30 pelanggan pelanggan yang hasil angketnya nilai di atas rata-rata $(42,90)$ sebanyak 18 atau $60 \%$ pelanggan sedangkan di bawah rata-rata sebanyak 12 pelanggan atau $40 \%$.

Kata Kunci: Kualitas Pelayanan, Kepuasan Pelanggan 


\section{PENDAHULUAN}

Globalisasi perekonomian membawa dampak pada perubahan lingkungan bisnis ke arah pentingnya pelayanan sebagai sumber keunggulan kompetitif perusahaan. Dalam era ekonomi berbasis pelayanan, pelayanan yang unggul (service excellence) menjadi kunci penentu kesuksesan perusahaan untuk membangun kekuatan persaingan dan memenangkan persaingan bisnis yang semakin ketat terutama dalam usaha bisnis penyedia pelayanan Jasa.

Perusahaan sebagai penyedia suatu produk atau jasa harus memperhatikan halhal yang bersifat internal, yaitu dengan cara memilih tenaga kerja yang terbaik dan mereka harus bekerja sebaik mungkin. Selain itu, perusahaan perlu menetapkan strategi pelayanan yang tepat melalui penciptaan kepuasan pelanggan untuk mencapai loyalitas pelanggan baik melalui penciptaan nilai bagi pelanggan maupun pemberian pelayanan yang tepat. Apa yang dilakukan oleh pegawai tersebut adalah merupakan produk perusahaan yang bertujuan untuk memuaskan pelanggan.

West Brook \& Reilly (dalam Tjiptono 2007: 349) berpendapat "kepuasan pelanggan merupakan respon emosional terhadap pengalaman-pengalaman berkaitan dengan produk atau jasa tertentu yang dibeli, gerai ritel, atau bahkan pola perilaku (seperti perilaku berbelanja dan perilaku pembeli), serta pasar secara keseluruhan".

Kepuasan pelanggan merupakan faktor yang penting bagi kelangsungan hidup usaha untuk bertahan dalam persaingan yang semakin ketat. Dengan cara mempertahankan pelanggan berarti mengharapkan pelanggan melakukan pembelian kembali atas produk dan jasa yang disediakan oleh perusahaan. Selain itu, perusahaan juga dapat meningkatkan pangsa pasarnya melalui kualitasnya, hal ini akan membawa dampak baik bagi perusahaan setelah melakukan serangkaian usaha seperti peningkatan kualitas yang merupakan kombinasi dan pengorbanan yang terjadi apabila pelanggan menggunakan suatu barang atau jasa untuk memenuhi kebutuhan para pelanggan dan meningkatkan kepercayaan pelanggan, serta meningkatkan hasil pencapaian perusahaan tersebut.

Anderson (dalam Lina Ananta, 2008: 70), menunjukkan hubungan antara kualitas pelayanan dengan kepuasan pelanggan, sebagai berikut "bahwa perbaikan kualitas pelayanan akan menghasilkan kepuasan pelanggan, oleh karena itu hubungan tersebut harus selalu ditingkatkan."

Kualitas merupakan hal terpenting dalam proses produksi suatu perusahaan. Dalam memilih suatu produk atau jasa seseorang para pelanggan lebih memilih produk dan jasa yang berkualitas yang sesuai dengan keinginan dan kebutuhannya para pelanggan.

Philip Kotler dan Kevin Lane (2009: 143) menjelaskan "kualitas adalah totalitas fitur dan karakteristik produk atau jasa yang bergantung pada kemampuannya untuk memuaskan kebutuhan yang dinyatakan atau tersirat".

Pada dasarnya dalam menjalankan usaha atau bisnis yang langsung dapat dirasakan oleh para pelanggan terutama pada usaha yang bergerak pada jasa servis motor atau juga disebut (AHASS). Penyedia jasa yang perlu diperhatikan tidak hanya produk, tetapi juga pelayanan jasanya seperti pelayanan servise, ganti oli, tune up, cuci gratis, dan pelayanan pembelian suku cadang. Sehingga dalam penyaluran produk yang dihasilkan, pelayanan yang diberikan kepada pelanggan bersifat langsung, yaitu dari perusahaan ke pelanggan dan bertujuan untuk memenuhi harapan para pelanggan.

Kotler et al (dalam Tjiptono, 2005: 2324) mendefinisikan "jasa sebagai tindakan atau perbuatan yang dapat ditawarkan oleh suatu pihak kepada pihak lain yang pada dasarnya bersifat intangible (tidak berwujud fisik) dan tidak menghasilkan kepemilikan sesuatu".

Dalam menjalankan usaha yang berkaitan dengan penyedia jasa dan produk 
perusahaan harus memperhatikan tidak hanya kualitas produk, tetapi juga terfokus pada kualitas pelayanan jasanya, sehingga perusahaan yang tersebut mampu memberi pelayanan yang berkualitas untuk tetap mempertahankan pelanggan.

Wyckof (dalam Levelock) (dalam Tjiptono, 2007: 260) menyatakan "Kualitas jasa merupakan tingkat keunggulan (excellence) yang diharapkan dan pengendalian atas keunggulan tersebut untuk memenuhi keinginan pelanggan".

Menurut Tjiptono (2000:126) bahwa sepuluh dimensi yang ada dapat dirangkum menjadi lima dimensi pokok menyangkut masalah kualitas pelayanan yaitu : (1) kehandalan (reliability), sebagai kemampuan perusahaan dalam melaksanakan jasa yang dijanjikan secara tepat dan terpercaya, (2) daya tanggap (responsiveness), yang menunjukkan kemauan untuk membantu pelanggan dan memberikan jasa dengan cepat atau tanggap, (3) jaminan (assurance) menunjukkan sejauh mana pengetahuan dan kesopanan karyawan serta kemampuan menciptakan image atau persepsi yang baik bagi perusahaan, dengan menumbuhkan kepercayaan dan keyakinan di benak konsumen terhadap perusahaan, (4) empati (empathy), sebagai syarat untuk peduli dan memberikan perhatian secara pribadi bagi pelanggan, dan (5) bukti fisik (tangible) berupa penampilan fasilitas fisik, peralatan, personel, dan media komunikasi.

Dimensi-dimensi inilah yang harus diperhatikan oleh perusahaan dalam bisnis eceran, sehingga berbagai pengalaman yang dapat mengakibatkan kegagalan tidak akan terjadi. Kualitas pelayanan harus sesuai dengan harapan yang diinginkan oleh setiap konsumen. Pada tingkat kesesuaian yang semakin tinggi antara harapan dengan kualitas pelayanan yang diberikan perusahaan, di situlah tercipta nilai kepuasan. Dalam menjalankan usaha penyedia jasa, CV. AHASS Kabul Motor Kecamatan Lembeyan Kabupaten Magetan menyadari pentingnya faktor kepuasan pelanggan. Rambat Lupiyoadi (2001:158) menyebutkan lima faktor utama yang harus diperhatikan oleh perusahaan dalam menentukan tingkat kepuasan pelanggan, yaitu :

1) Kualitas produk

2) Kualitas pelayanan

3) Emosional

4) Harga

5) Biaya

Kepuasan pelanggan terjadi setelah seorang pelanggan melakukan pembelian terhadap suatu barang atau jasa. Setelah adanya pembelian dan menggunakan produk atau jasa, seorang pelanggan melakukan evaluasi terhadap pelayanan yang diberikan. Seorang pelanggan merasa puas terhadap suatu produk barang dan jasa apabila pelayanan yang diberikan oleh suatu perusahaan sesuai dengan harapan dan keinginan pelanggannya.

Uchik Triswandari (2011) melakukan penelitian terhadap 100 orang pelanggan PT. PLN (Persero) Rayon Makasar Timur. Hasil penelitian menunjukkan bahwa kualitas pelayanan yang meliputi realibility, responsiveness, assurance, emphaty dan tangible berpengaruh positif terhadap kepuasan pelanggan. Dari lima variabel yang memoengaruhi kepuasan pelanggan PT. PLN (Persero) Rayon Makassar Timur, variabel yang paling dominan adalah variabel Assurance (Jaminan).

Penelitian ini merupakan replikasi dari penelitian Uchik Triswandari (2011). Perbedaannya adalah dari segi konsumen yang diteliti memiliki karakteristik yang berbeda, yaitu dalam hal daya beli, kelas sosial, dan gaya hidup.

\section{METODE PENELITIAN}

Penelitian dilakukan pada perusahaan CV. AHASS Kabul Motor di Kecamatan Lembeyan Kabupaten Magetan. Alasan pemilihan tempat tersebut dikarenakan CV. AHASS Kabul Motor merupakan perusahaan yang bergerak dan merupakan salah satu perusahaan yang menyediakan jasa pela- 
yanan perbaikan dan penjualan sepeda motor di wilayah Lembeyan yang sangat diminati oleh para pelanggan pengguna sepeda motor Honda, karena kualitas pelayanan terbaiknya. Untuk membuktikan hipotesis yang telah dikemukakan, maka dalam penelitian ini digunakan dua macam metode analisis, yaitu :

1. Analisis Kualitatif

Yaitu metode analisis yang digunakan dengan cara menjelaskan beberapa argumentasi yang berkaitan langsung dengan permasalahan. Dalam hal ini, penulis menggunakan beberapa teori atau konsep tentang perilaku konsumen.

\section{Analisis Kuantitatif}

Analisis yang menggunakan data-data yang dinyatakan dalam bentuk angka di mana data tersebut merupakan variabelvariabel yang dianggap berpengaruh terhadap perilaku konsumen dan pengaruhnya terhadap kepuasan pelanggan $\mathrm{CV}$. AHASS Kabul Motor yang terletak di Kecamatan Lembeyan Kabupaten Magetan dalam kategori-kategori yang pada akhirnya akan menjadi total skor dari pengisian kuesioner oleh responden.

Penelitian ini dilakukan untuk mengetahui apakah kualitas pelayanan jasa (X) berpengaruh terhadap kepuasan pelanggan (Y) pada CV. AHASS Kabul Motor Kecamatan Lembeyan Kabupaten Magetan.

\begin{tabular}{|c|c|}
\hline $\begin{array}{c}\text { Kualitas pelayanan } \\
(\mathrm{X})\end{array}$ & $\begin{array}{c}\text { Kepuasan pelanggan } \\
(\mathrm{Y})\end{array}$ \\
\hline
\end{tabular}

Gambar Rancangan Penelitian

Populasi dalam penelitian ini adalah pelanggan di CV. AHASS Kabul Motor yang terletak di Kecamatan Lembeyan Kabupaten Magetan.

Teknik sampling yang digunakan dalam penelitian ini adalah non probability sampling, yaitu proses pengambilan sampel yang tidak menjamin adanya peluang bahwa setiap unsur anggota populasi dipilih sebagai sampel (Sekaran, 2006:127).
Teknik pengambilan sampel dalam penelitian ini adalah dengan menggunakan metode convenience sampling, yaitu pengambilan sampel berdasarkan pada ketersediaan elemen dan kemudahan untuk mendapatkannya (Sekaran, 2006:136). Dengan kata lain sampel tersebut ada pada tempat dan waktu yang tepat. Sampel dalam penelitian ini adalah pelanggan yang datang ke lokasi penelitian pada saat peneliti menyebarkan angket. Adapun yang menjadi sampel dalam penelitian ini adalah pelanggan yang datang selama 1 minggu berjumlah 30 pelanggan.

\section{Teknik Pengumpulan Data}

Teknik pengumpulan data dalam penelitian adalah:

\section{Kuesioner}

Menurut Husaini Usman dan Purnomo Setiady A. (2004: 60) Angket ialah "daftar pernyataan atau pertanyaan yang dikirimkan kepada responden baik secara langsung atau tidak langsung (melalui pos atau perantara)". Pemberian kuesioner kepada responden bertujuan untuk memperoleh data yang obyektif dari responden, sehingga peneliti dapat mengetahui seberapa besar pengaruh kualitas pelayanan jasa terhadap kepuasan pelanggan.

Penelitian ini menggunakan kuesioner yang dibagikan kepada para responden, yaitu para pelanggan CV. AHASS Kabul Motor yang terletak di Kecamatan Lembeyan Kabupaten Magetan.

Kuesioner yang disebar untuk memperoleh data tentang tanggapan responden tentang kualitas pelayanan jasa dan kepuasan pelanggan. Kuesioner berisikan 25 daftar pernyataan yang terdiri dari 15 pernyataan kualitas pelayanan jasa dan 10 pernyataan kepuasan pelanggan.

\section{Observasi}

"Observasi atau pengamatan merupakan suatu teknik atau cara mengumpulkan data dengan jalan mengadakan pengamatan terhadap kegiatan yang sedang berlangsung" (Nana Syaodih S., 2011: 220). Pengamatan langsung terhadap obyek yang diteliti, yaitu 
CV. AHASS Kabul Motor yang terletak di Kecamatan Lembeyan Kabupaten Magetan.

\section{Dokumentasi}

Menurut (Nana Syaodihs S., 2011: 221)

Dokumentasi merupakan "suatu teknik kumpulan data dengan menghimpun dan menganalisis dokumen-dokumen baik, dokumen tertulis gambar maupun elektronik". Sedangkan menurut (Suharsimi Arikunto, 2010: 274). Metode dokumentasi, yaitu "mencari data mengenai hal-hal atau variabel yang berupa catatan, transkrip, buku, surat kabar, majalah, prasasti, notulen rapat, lengger, agenda, dan sebagainya”.

Dokumentasi dalam penelitian ini berupa daftar merk sepeda motor yang dijual di CV. AHASS Kabul Motor yang terletak di Kecamatan Lembeyan Kabupaten Magetan.

Instrumen yang digunakan dalam penelitian ini adalah kuesioner yang merupakan teknik pengumpulan data melalui daftar pernyataan yang diajukan kepada responden. Sistem yang digunakan berupa pemberian skor berdasarkan skala Likert.

Menurut Sukardi (2013 : 75), "secara fungsional kegunaan instrument penelitian adalah untuk memperoleh data yang diperlukan ketika peneliti sudah menginjak pada langkah pengumpulan informasi di lapangan".

Uji instrumen digunakan untuk menguji instrumen yang digunakan yaitu:

\section{Uji Validitas}

Menurut Husein Umar (2011 : 59), "validitas dalam penelitian dijelaskan sebagai suatu derajat ketepatan alat ukur penelitian tentang isi atau arti sebenarnya yang diukur".

\section{Uji Reliabilitas}

Menurut Suharsimi Arikunto (2013: 221), "reliabilitas menunjukkan pada satu pengertian bahwa sesuatu instrumen cukup dapat dipercaya untuk digunakan sebagai alat pengumpul data karena instrumen tersebut sudah baik".

Dalam menganalisis data menggunakan analisis linear sederhana. Di mana hanya ada satu variabel $\mathrm{X}$ yang mempengaruhi satu variabelY.
Teknik analisis data mengunakan SPSS for Windows 16.0. Teknik analisis data yang digunakan dalam penelitian ini adalah uji validitas guna untuk mengukur sah atau valid tidaknya suatu kuesioner. Untuk mengukur variabel kepuasan konsumen jawaban responden menggunakan analisis butir yaitu dengan cara skor-skor yang ada kemudian dikorelasikan dengan menggunakan rumus korelasi product moment.

Uji reabilitas menggunakan rumus uji cronbach's alpha. Metode pengambilan keputusan pada uji reabilitas biasanya menggunakan batasan 0,361. Reabilitas 0,361 adalah kurang baik, sedangkan di atas 0,361 adalah baik. 0,361 diambil dari tabel r. Untuk mengukur suatu kuesioner yang merupakan indikator dari variabel uji hipotesis dengan metode regresi linier sederhana dengan menggunakan uji $\mathrm{F}$ dan uji $\mathrm{t}$ untuk mengetahui signifikansi dari hipotesis dalam penelitian. Suatu kuesioner dikatakan reliable jika jawaban seseorang terhadap pertanyaan adalah konsisten atau stabil dari waktu ke waktu.

\section{HASIL PENELITIAN}

Dideskripsikan bahwa variabel kualitas pelayanan dengan jumlah data $(\mathrm{N})$ sebanyak 30 memiliki deskripsi data sebagai berikut: (a) Total skor sebesar 1860; (b) Nilai mean sebesar 62,00; (c) Nilai median sebesar 6200; (d) Nilai modus sebesar 58; (e) Standar deviasi sebesar 5,305; (f) Nilai minimum sebesar 49; (g) Nilai maksimum sebesar 70.

Hasil analisis kuesioner dari 30 pelanggan yang berada di atas nilai rata-rata $\geq$ 70 sebanyak 16 pelanggan atau 53,3\%, sedangkan yang di bawah rata-rata sebanyak 14 pelanggan atau $46,6 \%$. Hal ini dapat disimpulkan bahwa kualitas pelayanan jasa pada CV. AHASS Kabul Motor adalah baik, karena 78 pelanggan atau $97,5 \%$ berada di atas rata-rata.

Dideskripsikan bahwa variabel kepuasan pelanggan dengan jumlah data $(\mathrm{N})$ sebanyak 30 memiliki deskripsi data sebagai 
berikut: (a) Total skor sebesar 1287; (b) Nilai mean sebesar 42,00; (c) Nilai median sebesar 43,00; (d) Nilai modus sebesar 43; (e) Standar deviasi sebesar 3,960; (f) Nilai minimum sebesar 36; (g) Nilai maksimum sebesar 50.

Hasil analisis kuesioner dari 80 pelanggan yang berada di atas nilai rata-rata $\geq$ 50 sebanyak 19 pelanggan atau 63,3\%, sedangkan yang di bawah rata-rata sebanyak 11 pelanggan atau $36,6 \%$. Hal ini dapat disimpulkan bahwa kepuasan pelanggan pada CV.AHASS Kabul Motor adalah baik, karena 19 pelanggan atau $63,3 \%$ berada di atas ratarata.

\section{Hasil Uji Regresi}

Berdasarkan perhitungan di atas dapat diperoleh Persamaan Regresi diperoleh hasil $\mathrm{Y}=21,245+0,347 \mathrm{X}$. Artinya apabila kualitas pelayanan jasa meningkat sebanyak $1 \%$, maka kepuasan pelanggan akan meningkat sebesar 0,347 apabila faktor lain dianggap tetap.

\section{Hasil Uji Korelasi}

Untuk menguji hipotesis diperoleh $r_{\text {hitung }}(0,468) \geq r_{\text {tabel }}(0,361)$ berarti ada hubungan kualitas pelayanan jasa dengan kepuasan pelanggan pada CV. AHASS Kabul Motor .

\section{Hasil Uji F}

Jika nilai $\mathrm{F}_{\text {tabel }}$ 4,196 maka berdasarkan perhitungan berikut bahwa $\mathrm{F}_{\text {hitung }}\left(7,853 \geq \mathrm{F}_{\text {tabel }}\right.$ $(4,196)$. Sehingga dapat diartikan bahwa ada pengaruh antara kualitas pelayanan jasa terhadap kepuasan pelanggan pada CV. AHASS Kabul Motor .

\section{Hasil Uji T}

Jika $t_{\text {tabel }} 1,701$ berdasarkan perhitungan berikut bahwa $t_{\text {hitung }}(2,794) \geq t_{\text {tabel }}(1,701)$ dapat diartikan ada beda pengaruh kualitas pelayanan jasa terhadap kepuasan pelanggan pada CV.AHASS Kabul Motor .

\section{PENUTUP}

\section{Simpulan}

Berdasarkan analisis data yang diperoleh dari hasil penelitian tentang pengaruh kualitas Pelayanan Jasa terhadap kepuasan pelanggan pada CV. AHASS Kabul Motor yang telah dilakukan maka dapat diambil kesimpulan sebagai berikut:

1. Kualitas pelayanan jasa pada CV. AHASS Kabul Motor Kecamatan Lembeyan Kabupaten Magetan baik. Hal ini dapat diketahui dari hasil analisis dengan jumlah data sebanyak 30 pelanggan pelanggan yang hasil angketnya nilai di atas rata-rata (62) sebanyak 17 pelanggan atau 57\% sedangkan di bawah rata-rata sebanyak 13 atau $43 \%$.

2. Pelanggan CV. AHASS Kabul Motor Lembeyan Kabupaten Magetan puas dengan pelayanan jasa yang telah diterima. Hal ini dapat diketahui dari hasil analisis dengan jumlah data sebanyak 30 pelanggan yang hasil angketnya nilai di atas rata-rata $(42,90)$ sebanyak 18 atau $60 \%$ pelanggan sedangkan di bawah ratarata sebanyak 12 pelanggan atau $40 \%$.

3. Kualitas pelayanan jasa mempunyai pengaruh terhadap kepuasan pelanggan pada CV. AHASS Kabul Motor Lembeyan Magetan. Hal ini dapat dilihat dari :

a. Uji Regresi, yaitu Y $=21,24+0,347 \mathrm{X}$. Artinya apabila kualitas pelayanan jasa meningkat sebanyak $1 \%$, maka kepuasan pelanggan akan meningkat sebesar 0,347, apabila faktor lain dianggap tetap.

b. Uji Korelasi, yaitu $\mathrm{r}_{\text {hitung }}$ sebesar 0,468 sedangkan $\mathrm{r}_{\text {tabel }}$ sebesar 0,361. Hal ini berarti nilai $r_{\text {hitung }} \geq r_{\text {tabel }}(0,468 \geq 0,361)$. Artinya ada hubungan kualitas pelayanan jasa terhadap kepuasan pelanggan di CV. AHASS Kabul Motor Lembeyan Magetan.

c. Uji F, yaitu $F_{\text {hitung }}$ sebesar 7,853 sedangkan $\mathrm{F}_{\text {tabel }}$ sebesar 4,196. Hal ini berarti $\mathrm{F}_{\text {hitung }} \geq \mathrm{F}_{\text {tabel }}(7,853 \geq 4,196)$. 
Artinya ada pengaruh antara kualitas pelayanan jasa terhadap kepuasan pelanggan.

d. Uji T, yaitu $\mathrm{T}_{\text {hitung }}$ sebesar 2,794, sedangkan $\mathrm{T}_{\text {tabel }}$ sebesar 1,701. Hal ini berarti $\mathrm{T}_{\text {hitung }} \geq \mathrm{T}_{\text {tabel }}(2,794 \geq 1,701)$. Artinya ada beda pengaruh antara kualitas pelayanan jasa terhadap kepuasan pelanggan di CV. AHASS Kabul Motor Lembeyan Magetan.

\section{Saran}

Agar CV. AHASS Kabul Motor Lembeyan Magetan bisa lebih meningkatkan kepuasan pelanggan maka perlu melakukan beberapa langkah sebagai berikut:

1. Karyawan diharapkan terampil dan mempunyai pengetahuan yang memadai, karena Assurance mempunyai pengaruh besar terhadap kepuasan pelanggan, dan cara berkomunikasi yang baik dengan pelanggan, sopan dan ramah kepada pelanggan, serta mampu memenuhi kebutuhan dan keinginan para pelanggan juga perlu diperhatikan.

2. Sebaiknya karyawan lebih cepat dalam melayani pelanggan, yang bertugas mengatasi keluhan atau permasalahan yang dihadapi pelanggan. Karena responsiveness juga mempunyai pengaruh terhadap kepuasan pelanggan.

3. CV. AHASS Kabul Motor Lembeyan Magetan dalam melakukan penataan interior dan eksterior tetapi rapi, seperti, kursi untuk tempat duduk pelanggan ditata secara per baris sehingga lebih rapi serta setiap ruangan selalu dibersihkan setiap saat agar terlihat bersih dan menggunakan teknologi yang lebih canggih dalam memberikan pelayanan. Karena tangible juga mempunyai pengaruh terhadap kepuasan pelanggan.

\section{DAFTAR PUSTAKA}

Buchari Alma. 2004, Manajemen Pemasaran dan Pemasaran Jasa, Bandung: CV Alfabeta.
Christopher Luvelock, dkk. 2010, Pemasaran Jasa Manusia, Teknologi, Strategi Perspektif Indonesia Jilid I. Jakarta: Erlangga.

Fandy Tjiptono. 2005, Prinsip-prinsip Total Quality Service. Yogyakarta: CV. Andi Offset. 2007, Pemasaran Jasa.

Malang: Banyumedia Publishing.

Fandy Tjiptono dan Gregorius Chandra. 2011, Service, Quality \& Satisfaction. Yogyakarta: Andi Offset.

Gabriel Amin Silalahi. 2003. Metodologi Penelitian dan Studi Kasus. Sidoarjo: CV.Citra Media.

Gunawan Adisaputro. 2010, Manajemen Pemasaran Analisis untuk Perancangan Strategi Pemasaran. Yogyakarta: Sekolah Penerbit dan Percetakan.

Hamid Darmadi. 2011. Metode Penelitian Pendidikan. Bandung: Alfabeta.

Husaini Usman dan Purnomo Setiady Akbar. 2004. Metodologi Penelitian Sosial. Jakarta: Bumi Aksara.

Husain Umar. 2011. Metode Penelitian untuk Skripsi dan Tesis Bisnis. Jakarta: PT. Raja Grafindo Persada.

Juliansyah Noor. 2011. Metodologi Penelitian. Jakarta: Kencana Penanda Media Grup.

Lina Ananta 2008, SERVICE EXCELLENCE Competing Through Competitiveness. Bandung: Alfabeta.

M. Nur Nasution. 2004. Manajemen Jasa Terpadu (Total Service Management). Bogor Selatan: Ghalia Indonesia.

Nana Syaodik S. 2011. Metode Penelitian Pendidikan. Bandung: Remaja Rosdakarya.

Philip Kotler. 2009. Manajemen Pemasaran, Edisi ke Tiga Belas. Jakarta: Erlangga. 
Retno Widyaningrum. 2011, Statistika. Yogyakarta: Pustaka Felicha.

Rambat Lupiyoadi. 2001, Manajemen Pemasaran Jasa. Jakarta: Salemba Empat.

Sekaran, Uma. 2006. Research Methods for Business Edisi IV. Jakarta: Salemba Empat.

Suharsimi Arikunto. 2002. Prosedur Penelitian Suatu Pendekatan Praktik. Jakarta: Rineka Cipta.

2010. Prosedur Penelitian Suatu Pendekatan Praktik. Jakarta: Rineka Cipta.
Sugiyono. 2010. Metode Penelitian Pendidikan (Pendekatan Kuantitatif, Kualitatif dan R\&D). Bandung: Alfabeta.

2013. Metode Penelitian Kombinasi (Mixsed Methods). Bandung: Alfabeta.

Syofian Siregar. 2012. Statistika Deskriptif untuk Penelitian. Jakarta: Rajagrafindo Persada.

Usman Rianse dan Abdi. 2012. Metodologi Penelitian Sosial dan Ekonomi Bandung: Alfabeta.

Zulian Yumit. 2005, Manajemen Kualitas Produk dan Jasa. Yogyakarta: Ekonisia 